\title{
Transcription Factor HES-1
}

National Cancer Institute

\section{Source}

National Cancer Institute. Transcription Factor HES-1. NCI Thesaurus. Code C84294.

Transcription factor HES-1 (280 aa, $\sim 30 \mathrm{kDa}$ ) is encoded by the human HES1 gene. This protein plays a role in transcriptional regulation. 